\title{
Lado Kranjčević
}

E-mail: lado.kranjcevic@riteh.hr

\section{Luka Grbčić}

E-mail: luka.grbcic@riteh.hr

\section{Matija Mrazović}

E-mail: matija.mrazovic@riteh.hr

Siniša Družeta

E-mail: sinisa.druzeta@riteh.hr

University of Rijeka, Faculty of Engineering

Vukovarska 58, 51000 Rijeka, Croatia

\section{Rijeka Bay 3D VOF Costal Flow Model}

\begin{abstract}
3D multiphase flow was analyzed in the area of Rijeka bay in the Adriatic Sea. The necessary morphology data in the range of interest of the coastal bottom area were collected and the spatial surface was created. The functionality of the 3D model was studied in the large area of the realistic stochastic structure of the bottom and the shore. The probability of meteorological conditions and wind impact in the model has been shown. The obtained results give a detailed view of the velocity fields in the horizontal plane of different depths.

Numerical simulation was performed in open source program OpenFOAM with Volume of Fluid (VOF) method using the Eulerian approach. For solving this problem interFOAM solver for two incompressible, isothermal, immiscible fluids was used. The resulting simulations showed dominant flow from the western coast of the Krk island to the eastern coast of the Istrian peninsula. Seawater enters the bay through the Srednja Vrata and Tihi Kanal and exits the bay through the Vela Vrata. This research has shown that using a VOF method can be successfully implemented for describing fluid motion in large areas such as bays and oceans.
\end{abstract}

Keywords: flow simulation, costal sea motion, numerical model, OpenFOAM, Rijeka bay

\section{Introduction}

The Kvarner Bay is located on the northeastern part of the Adriatic Sea which is divided into large parts by large island series. The northern part of Kvarner is called Rijeka Bay. Between Croatian Littoral and the island of Krk, Pag and Rab are the Velebit-Vinodol Channel. Kvarnerić is part of the Bay bordered between the islands of Krk, Rab, Pag, Cres, and Lošinj. The term Kvarner in the narrow sense refers to 
the area bounded on the western side by the Istrian peninsula, and on the east by the island of Krk, while between them extends the island of Cres. On the northern side of the Kvarner Bay are the Croatian Littoral and the city of Rijeka with the largest port in Croatia.

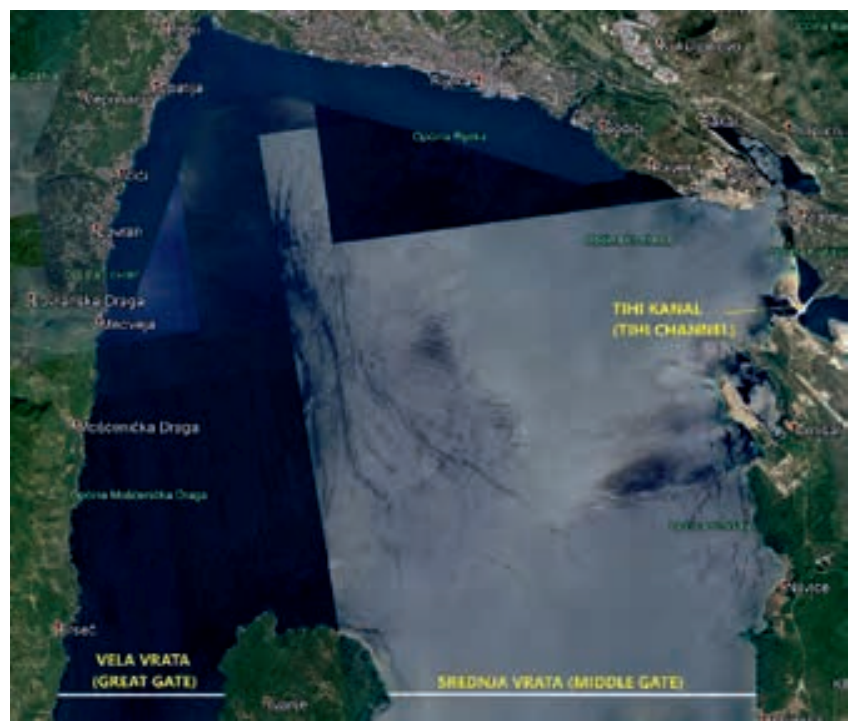

Figure 1: Rijeka bay

In the Bay, seawater is exchanging through the Srednja and Vela Vrata and Tihi Kanal channel. Vela Vrata is located between the Istrian peninsula and the Island of Cres, the width of the passage shown in Figure 1. is $5.1 \mathrm{~km}$ and the maximum depth is $65 \mathrm{~m}$. Significant maritime routes also pass through the bay, mostly through the Srednja Vrata between the islands of Cres and Krk through a $13 \mathrm{~km}$ wide passage. The water also exchanges through the Tihi Kanal. In the middle of the Tihi Kanal lies the island of Sveti Marko, which divides it into two entrances of width 958 and $790 \mathrm{~m}$. The depth of the sea in the southern part of Kvarner Bay is decreased, mostly uniform and ranges from $45-55 \mathrm{~m}$, and all coasts of Istria and Cres are relatively steep descending to the sea depths.

It is important to mention the hydrographic characteristics of Rijeka Bay which depend on the seasonal thermohaline cycle, the inflow of freshwater, currents and meteorological conditions. It was noticed that changes in the surface layer are much more pronounced than in the bottom layer. The intermediate layer is characterized by the thermocline in the summer period, which stratifies the surface layer from the bottom layer. The bottom layer has much more homogenous characteristics, both geographical and seasonal. During the summer, when bottom currents are of the lowest intensity, the temperature, salinity, and density of the bottom layer vary a little. During the winter, 
because of convective mixing, the temperature tends to equalize in the water column. The inflow from freshwater in numerous bottom wells located in Bakar Bay and on the northern coast of Rijeka Bay is most intensive in winter. For that reason, stratification of the water column in the winter period is determined by differences in salinity. [1]

In terms of climate, the Adriatic Sea is situated between the subtropical highpressure zone and the mid-latitude or westerlies belt, in which atmospheric disturbances generally move from west to east. These zones shift throughout the year "cum sole", causing sharp seasonal differences. Through most of the year, the effects of the westerlies belt dominate the region, with frequent cyclones and anticyclones appearing in the lower troposphere. During the summer, the subtropical high-pressure zone dominates and the cyclonic and anticyclonic disturbances of the westerlies belt all but disappear from the Adriatic [2].

The aim of the paper was primarily to present a model of flow that could be implemented in the case of various accidents because the Adriatic Sea is covered by important oil transport routes from the Otranto Strait to the northern Adriatic ports (Trieste, Venice, Omišalj, and Koper), transporting around $58 \mathrm{t}$ of oil annually [3]. Various turbulent models were tested, such as k-Epsilon and k-Omega, and a comparison is provided. There are many different motives for modeling the Bay with the CFD method, and some of them are the ability to monitor pollutants from the Delta sewage outlet, the input of river Rječina pollution and other underground and torrential discharges, discharges from the Urinj industrial plant, possible discharges from the Urinj oil storage facility, the Omišalj-Urinj submarine pipeline burst and the ability to act in the event of a tanker crash Along the eastern coast, there are numerous submarine springs that discharge freshwater originating in the littoral karst area, [4] but are probably not of major importance. The high ecological vulnerability of the Kvarner and Rijeka Bays due to the semiclosed geolocation along with the intensive tanker transport and oil transshipment in the Omišalj terminal, [5] is a good enough motive to create this $3 \mathrm{D}$ flow model.

\section{Material and Methods}

Numerical simulation was performed in the open-source computational fluid dynamics (CFD) program OpenFOAM [6] which is based on the finite volume method. The multiphase OpenFOAM solver interFoam was used to model the described problem. The interFoam solver solves the isothermal and incompressible NavierStokes equation along with the Volume of Fluid (VOF) Method which describes the interaction between two immiscible phases, air, and water. The Navier-Stokes equations

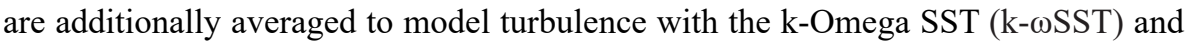

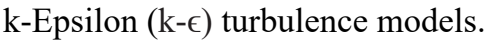




\subsection{VOF Method}

In the conventional VOF method, the transport equation for an indicator function, representing the volume fraction of one phase, is solved simultaneously with the continuity and momentum equations. The volume fraction $\alpha$ takes on values in the range, where indicates that there is only air in the cell and only water for $\alpha=1$.

$$
\begin{aligned}
& \rho=\alpha \rho_{l}+(1-\alpha) \rho g \\
& \frac{\partial \alpha}{\partial \mathrm{t}}+(\alpha \mathrm{u})+\nabla\left(\alpha(1-\alpha) \mathrm{u}_{r}=0\right.
\end{aligned}
$$

where $\rho_{l}$ and $\rho_{g}$ are the densities of fluid and air, respectively.

\subsection{Numerical domain}

The structure of the spatial domain of the Rijeka Bay is visible in Figure 2.. The maximum depth is $79 \mathrm{~m}$, while it averages $60 \mathrm{~m}$.

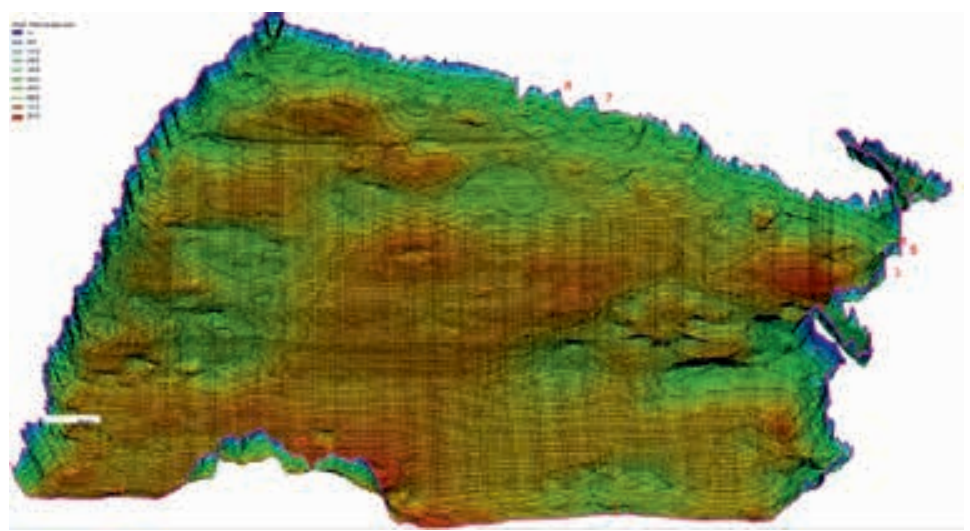

Figure 2: Seabed surface structure

From the created bathymetry, a 3D domain was obtained on which the simulation was performed. Vertically above the surface of the sea, the geometry was raised by $42 \mathrm{~m}$ for easier defining the interaction between water and air and creating boundary conditions. The domain was meshed using the snappyHexMesh tool within OpenFOAM and contains 7096684 hexahedral elements and it can be seen in Figure 3. 


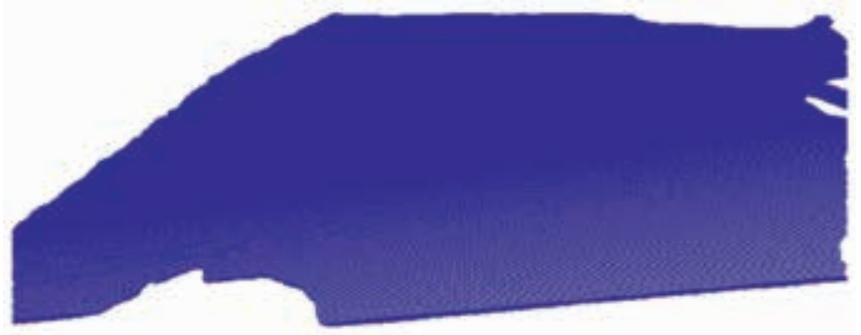

Figure 3: Meshed domain

The entire domain bottom velocity boundary condition was set to noslip, while the Tihi Kanal (simplified in the numerical domain as opposed to realistic geometry) was defined as inflow, as was the Srednja Vrata while the Vela Vrata was defined as outflow (all boundaries can be seen in Figure 1.). The top layer of the surface served as the atmosphere where a reference pressure was defined.

Water enters the bay through Srednja Vrata and the Tihi Kanal and it passes along the western coast of the island of Krk and exits through the Vela Vrata along the eastern coast of the Istrian peninsula and the island of Cres. The largest river that flows into the Bay of Rijeka is Rječina River, with a length of $17 \mathrm{~km}$ approximately. Water enters the bay at delta width of about $15 \mathrm{~m}$, while the flow varies from 10 do 50 depending on the season [6].

\section{Results}

The simulation results are presented in the form of velocity fields and streamlines in the observed domain. The simulation time is $8000 \mathrm{~s}$, which is 2 hours 13 minutes on the Bura supercomputer of the Center for Advanced Computing and Modelling at the University of Rijeka. In Figure 4. the velocity results at a depth of $3 \mathrm{~m}$ above the surface can be seen for both turbulence models which were used. It can be seen that both models provide similar results.
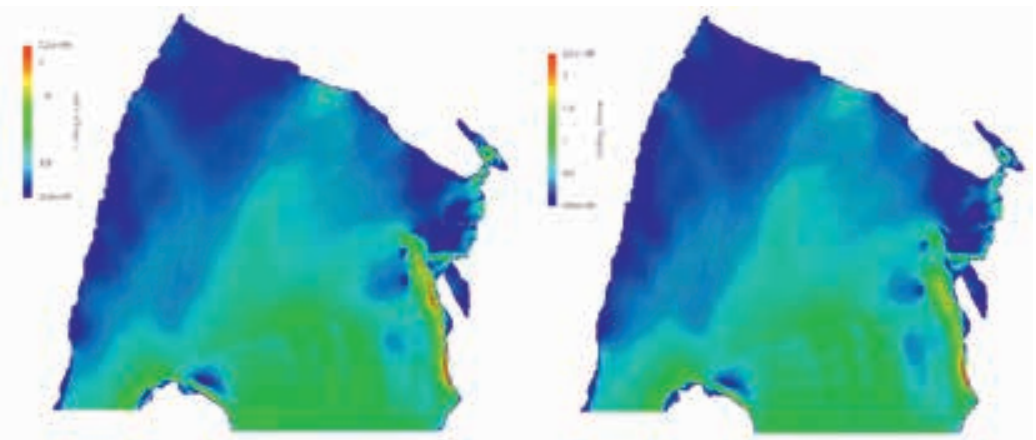

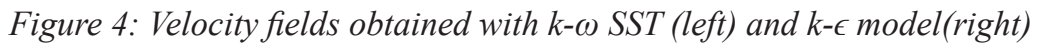


In Figure 5. the velocity streamlines where water enters the Bay through the Srednja Vrata and exits through the Vela Vrata at a depth of $3 \mathrm{~m}$ above surface can be seen for both turbulence models which were used to better visualize the dynamics of flow and vortex structures.
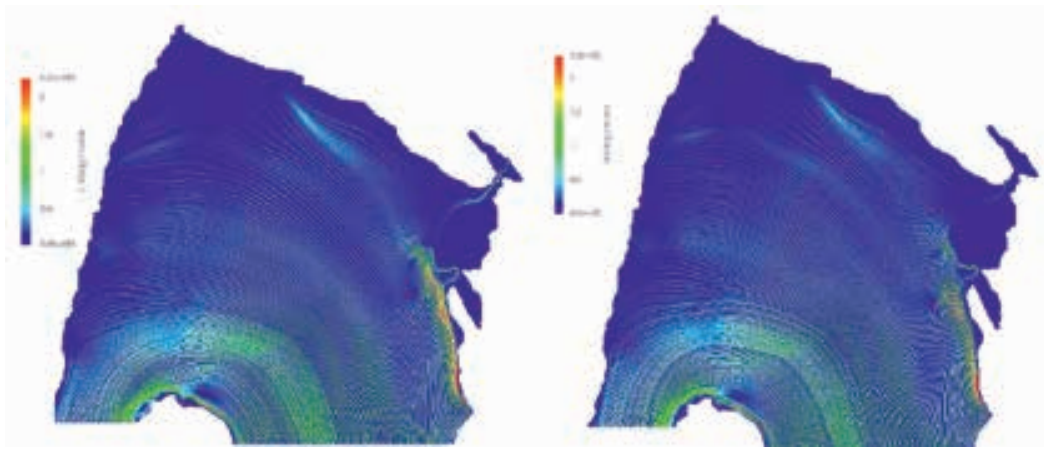

Figure 5: Streamlines at a depth of 3 m obtained with $k-\omega S S T$ (left) and $k$ - $\epsilon$ model (right)

Figure 6. shows the streamlines right where water enters the Bay through the northern section of Tihi Kanal while Figure 7. shows the water inflow from the southern part of the Tihi Kanal. It is important to mention that the numerical domain was simplified and the inflows were set as boundary conditions. Figure 8. shows the vector magnitude velocity field and includes all of the inflows.
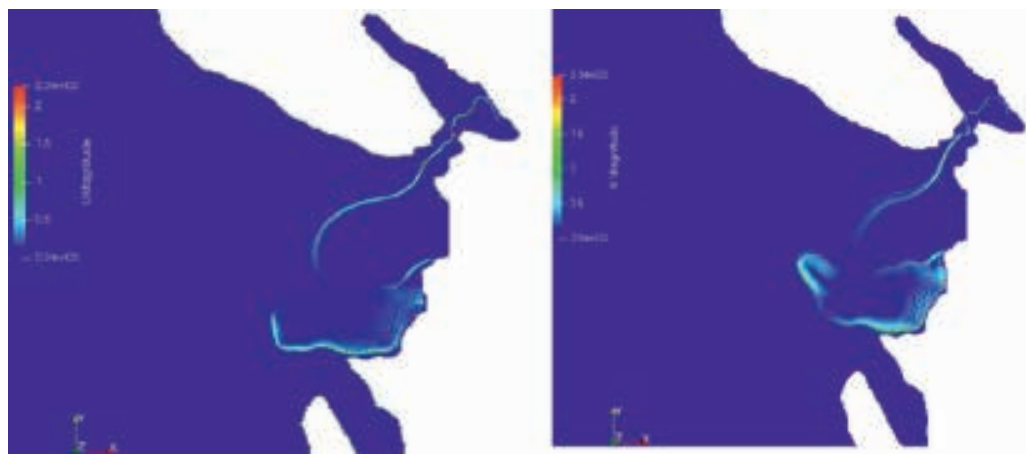

Figure 6: Streamlines at a depth of 3 m obtained with $k-\omega$ SST (left) and $k$ - $\epsilon$ model (right) 

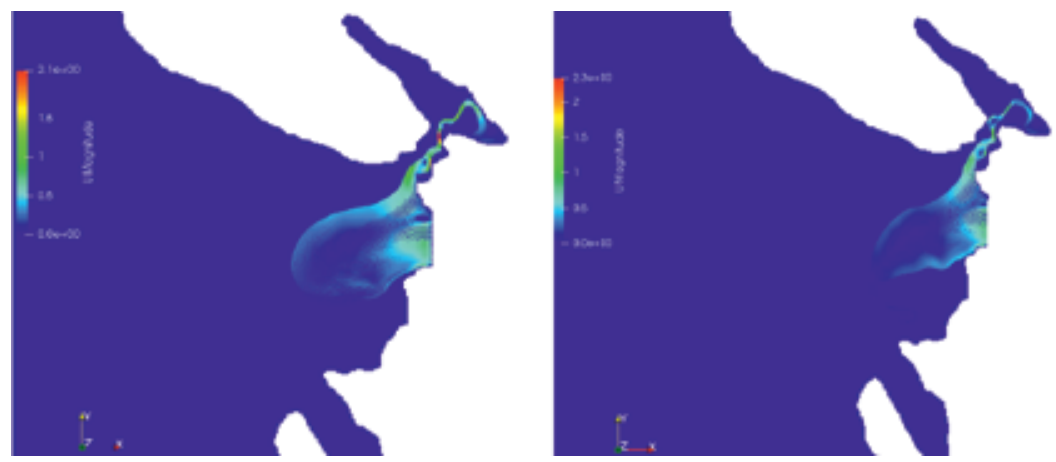

Figure 7: Streamlines at a depth of 3 m obtained with $k$ - $\omega$ SST (left) and k- $\epsilon$ model (right)

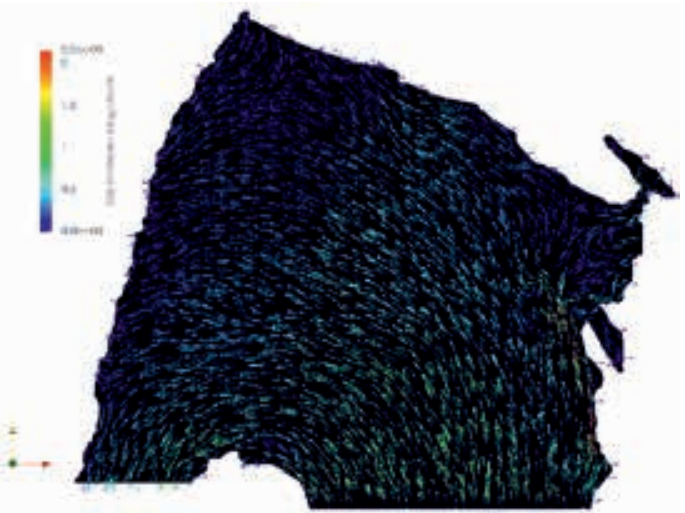

Figure 8: Velocity magnitude vectors at a depth of $3 \mathrm{~m}$

\section{Conclusion}

The 3D multiphase flow was analyzed in the area of Rijeka bay in the Adriatic Sea using the open-source program OpenFOAM which has proved to be useful in modeling coastal flow. An interFoam solver was used and two turbulent models, k- $\epsilon$ and k- $\omega$ SST, were compared. There are many motivations for CFD modeling of the Bay, some of them include the possibility of monitoring the pollutants from the Delta sewage, the input of river pollution, various torrential discharges and the monitoring of pollution in the event of various disasters, with a small adjustment.

The results showed that the movement of the sea currents in Rijeka Bay is relatively complex and non-stationary. Also, the movement of the seawater in the bay was confirmed and it was concluded that seawater enters the bay through the Srednja Vrata and the Tihi Kanal, moves along the western coast of the island of Krk 
and exits through the Vela Vrata along the eastern coast of the Istrian peninsula. The paper neglects the case of sea stratification, and water flows through the entire column through the Srednja Vrata and exits through the Vela Vrata, which corresponds to the case of flow in the winter.

In general, flow control allows us to manage ecologically in the Rijeka Bay, where industrial facilities coexist along with tourist areas intended for swimming and recreation in the waters important for fisheries.

\section{References}

1. IVIĆ, STEFAN, MRŠA, HEBER IVA, LEGOVIĆ, TARZAN: „,Lagrangian Coherent Structures in the Rijeka Bay Current Field", Acta Adriatica, 2017.

2. ORLIĆ, MIRKO, GAČIĆ, MIROSLAV, ELA, VIOLETTE PAUL: , The Currents and Circulation of the Adriatic Sea “, Oceanologica Acta -vol. 15 -n², 1992.

3. LONČAR, J., MARADIN, M.: „Environmental Challenges Sustainable Development in the Croatian North Adriatic Littoral Region ", Razgledi, 2009.

4. ALFIREVIĆ, S.: ,, Adriatic Submarine Springs in the Water System of the Dinaric Karst Littoral and their Problems “, Krš Jugosl., 6,183-205, 1969.

5. LONČAR, G., BEG PAKLAR, GORDANA, JANEKOVIĆ, IVICA: „Numerical Modelling of Oil Spills in the Area of Kvarner and Rijeka Bay (The Northern Adriatic Sea) ", Journal of Applied Mathematics, 8. lipanj 2012.

6. JASAK, HRVOJE, JEMCOV, ALEKSANDAR, TUKOVIĆ, ŽELJKO: OpenFOAM: A C++ library for complex physics simulations. International workshop on coupled methods in numerical dynamics. Vol. 1000. IUC Dubrovnik Croatia, 2007.

7. MRŠA HABER, IVA, LEGOVIĆ, TARZAN, CUKROV, MARIJAN: Numerical Simulation of Rijeka Bay Water Dynamics for Most Common Winds, Transactions of FAMENA, 2018. 